\title{
Peran Orang Tua dan Guru untuk Mengembangkan Perilaku Moral dan Religiusitas Remaja
}

\author{
Fitri Awan Arif Firmansyah \\ Program Studi Psikologi, Fakultas Psikologi, \\ Universitas Selamat Sri, Kendal, Jawa Tengah \\ fitriawanarif@gmail.com
}

\begin{abstract}
Abstrak
Kenakalan remaja adalah suatu perbuatan yang melanggar norma. Perilaku tersebut merupakan problema yang bisa terjadi di lingkungan keluarga, sekolah, maupun masyarakat. Kenakalan remaja di lingkungan rumah misalnnya tindakan indisipliner, melawan orang tua, berkelahi dengan saudara. Salah satu penyebab kenakalan dikalangan remaja, yaitu kurangnya religiusitas yang ada pada diri remaja. Hal ini pun dikarenakan banyak orang tua yang masih belum berkontribusi penuh dalam pembentukan perilaku moral dan religiusitas anak. Di sisi lain, peran guru sebagai pendidik di luar rumah juga sangat penting. Namun, dalam perannya pun kurang maksimal karena masih banyak guru yang sekadar fokus pada nilai, tapi abai pada pembentukan karakter nilai moral. Padahal, pendidikan yang baik sejak dini baik di keluarga dan sekolah sangatlah diperlukan guna membentuk kepribadian yang berakhlak, bermoral, serta bijak dalam menghadapi perkembangan zaman. Terkait dengan hal tersebut, tujuan penelitian ini untuk mengetahui peran yang dilakukan oleh guru dan orang tua untuk membentuk perilaku moral dan religiusitas remaja. Metode penelitian yang digunakan adalah kualitatif deskriptif. Teknik pengumpulan data berupa wawancara mendalam dan dokumentasi. Dari hasil penelitian ditemukan bahwa guru dan orang tua mempunyai berbagai cara dalam mengembangkan religiusitas dan perilaku moral remaja seperti melakukan pengawasan, mebmerikan contoh, memberikan kebiasaan yang baik, dan menyisipkan ceramah dalam mata pelajaran.
\end{abstract}

Kata Kunci: Orang Tua; Guru; Religiusitas; Perilaku Moral; Remaja.

\section{PENDAHULUAN}

Pada zaman sekarang ini, kemajuan melaju pesat diberbagai bidang khususnya IPTEK. Hal ini membuat berbagai informasi baik dari dalam maupun luar negeri mudah diakses, khususnya remaja. Informasi yang diperoleh bisa saja memberikan dampak positif maupun negatif bagi remaja yang mengaksesnya. Bagi remaja yang sedang mencari jati diri dan tidak dibentengi dengan pedoman agama yang baik rentan terpengaruh oleh budaya yang tidak baik. Tugas perkembangan yang penting dalam masa remaja awal adalah 
memahami dan mengubah sikap-sikapnya sesuai dengan harapan-harapan kelompok tanpa selalu dibimbing, diawasi, dan diancam oleh orang-orang dewasa. Untuk mencapai hal tersebut remaja harus memiliki pengawasan dari dalam atau"internal control". Apabila pada masa kanak-kanak sudah tertanam konsep kesusilaan atau dalam istilah lain sering disebut dengan moral.

Peran keluarga, sekolah, dan lingkungan dalam mengajarkan nilai-nilai moral dan agama kepada remaja merupakan bekal untuk menjalani masa remaja yang produktif. Keluarga, sekolah, dan lingkungan hendaknya mendampingi dan membimbing remaja agar tidak terpengaruh oleh budaya-budaya negatif yang membuat mereka terjebak ke dalam pergaulan bebas. Namun, terkadang tidak adanya perasaan saling percaya membuat hubungan antara orang tua dan anak menjadi renggang. Orang tua yang cenderung bersikap keras kepada remaja dan remaja yang merasa bingung dengan jati dirinya membuat mereka berontak terhadap orang tuanya. Akhirnya mereka lebih memilih bertindak dan meniru perbuatan sesuai dengan yang diinginkannya. Gunarsa (2013) perilaku adalah segala sesuatu atau tindakan yang sesuai dengan nilai-nilai tata cara yang ada dalam suatu kelompok. Perilaku di sini adalah tindakan-tindakan yang dilakukan oleh seseorang sesuai dengan nilai-nilai dalam masyarakat. Selaras dengan itu, Hurlock (1999) berpendapat bahwa perilaku moral merupakan perilaku yang sesuai dengan kode moral kelompok sosial. Perilaku moral ini dikendalikan oleh konsep-konsep moral peraturan perilaku yang telah menjadi kebiasaan bagi anggota suatu budaya dan yang menentukan pola perilaku yang diharapkan dari seluruh anggota kelompok.

Setiap orang tua tentu menginginkan anaknya menjadi orang yang berkembang secara sempurna. Mereka menginginkan anak yang kelak menjadi orang yang sehat, kuat, berketrampilan, cerdas, pandai dan beriman. Dari hal tersebut, orang tua tidak menginginkan anaknya menjadi bodoh atau nakal. Menurut beliau, ada dua arah pendidikan religiusitas dalam rumah tangga, pertama penanaman nilai-nilai dalam arti pandangan hidup yang kelak akan mewarnai perkembangan jasmani dan akalnya. Kedua, penanaman sikap yang kelak menjadi basis dalam menghargai guru dan pengetahuan di sekolah.

Religiusitas yang ditanamkan orang tua sangat berperan dalam pembentukan perilaku moral remaja. Pembentukan tersebut akan membawa anak dalam pertumbuhan dan perkembangan yang baik. Remaja memerlukan pendidikan dan persyaratan, pengawasan, dan pemeliharaan yang terus menerus. Pendidikan dan pengetahuan mengenai agama sangat dibutuhkan oleh remaja agar dapat bersikap sebagaimana mestinya. Selain itu, remaja juga wajib diajarkan makna dari nilai-nilai agama agar sikap religiusitasnya lebih kuat tertanam dalam karakter diri dan hati mereka. Sebab acap kali terlihat pengamalan agama tanpa diikuti dengan pemahaman makna agama, maka lebih condong akan membuat anak sukar melaksanakan nilai-nilai religi yang diajarkan oleh kedua orang tuanya. Jika terus berkelanjutan, dapat menyebabkan anak merasa tidak memiliki beban moral apabila tidak melaksanakan nilai-nilai agama atau merasa santai saja ketika melakukan tindakan yang salah. 
Menurut Muhyani (2012) menjelaskan bahwa religius merupakan ekspresi spiritual seseorang yang berkaitan dengan sistem keyakinan, nilai, hukum yang berlaku. Religiusitas diwujudkan dalam berbagai sisi kehidupan, bukan hanya terjadi ketika seseorang melakukan ritual agama yang dianutnya saja, tetapi juga ketika melakukan aktivitasaktivitas lainnya yang didorong oleh kekuatan supranatural. Setiap orang tua juga pasti memiliki berbagai harapan-harapan. Misalnya, anak harus lebih baik dari pada orang tuanya. Dari hasil pengalamannya, orang tua berusaha mengajarkan pengetahuanpengetahuan maupun perilaku yang mulia dari segi tutur kata, perilaku, dan sopan santun. Orang tua juga perlu waspada terhadap kondisi lingkungan yang mencerminkan kemerosotan moral.

Orang tua berkewajiban memberikan bimbingan serta melakukan kontrol terhadap anak-anaknya. Selain itu, masa remaja juga dikatakan sebagai suatu masa yang berbahaya dan krisis karena masa transisi dari kekanak-kanakan dan masa pembentukan kepribadian yang disertai minimnya pegangan. Oleh karena itu peran orang tua menjadi sangat penting sebagai contoh ideal dalam pandangan anak, tingkah laku, dan bersopan santun. Namun, memang terkadang orang tua belum dapat sepenuhnya menjalankan peran sebagai sosok penuntun dan teladan dalam pembentukan kepribadian anak. Latar belakang pendidikan, jenis pekerjaan, dan juga tersedianya waktu untuk mendampingi anak masih menjadi kendala serius dalam hal ini.

Wirawan (2002) menjelaskan bahwa untuk mendefinisikan remaja seharusnya disesuaikan dengan budaya setempat. Di Indonesia fase yang terjadi pada usia 11-24 dijelaskan sebagai berikut. (1) Usia 11 tahun adalah usia tanda-tanda sekunder mulai tampak. (2) Usia 11 tahun sudah dianggap akil balig, baik menurut adat maupun agama sehingga masyarakat tidak lagi memperlakukan mereka sebagai anak-anak. (3) Pada usia tersebut mulai ada tanda-tanda penyempurnaan perkembangan jiwa seperti tercapainya identitas ego, tercapainya fase genital dari perkembangan psikoseksual, dan tercapainya puncak perkembangan kognitif, maupun moral. (4) Batas usia 24 tahun merupakan batas maksimal, yaitu untuk memberi peluang bagi mereka yang sampai batas usia tersebut masih menggantungkan diri pada orang tua, belum mempunyai hak-hak penuh sebagai orang tua. (5) Dalam definisi tersebut, status perkawinan sangat menentukan apakah individu masih digolongkan sebagai remaja ataukah tidak.

Seperti halnya pada semua periode yang penting, sela rentang kehidupan masa remaja mempunyai ciri-ciri tertentu yang membedakannya dengan periode sebelumnya dan sesudahnya. Masa remaja ini, selalu merupakan masa-masa sulit bagi remaja maupun orangtuanya. Menurut Sidik (2010) kesulitan itu berangkat dari fenomena remaja sendiri dengan beberapa perilaku khusus sebagai berikut. (1) Remaja mulai menyampaikan kebebasannya dan haknya untuk mengemukakan pendapatnya sendiri. Tidak terhindarkan, ini dapat menciptakan ketegangan dan perselisihan, dan bias menjauhkan remaja dari keluarganya. (2) Remaja lebih mudah dipengaruhi oleh teman-temannya daripada ketika mereka masih kanak-kanak. Ini berarti bahwa pengaruh orangtua semakin lemah. Anak 
remaja berperilaku dan mempunyai kesenangan yang berbeda bahkan bertentangan dengan perilaku dan kesenangan keluarga. Contoh-contoh yang umum adalah dalam hal mode pakaian, potongan rambut, kesenangan musik yang kesemuanya harus mutakhir. (3) Remaja mengalami perubahan fisik yang luar biasa, baik pertumbuhannya maupun seksualitasnya. Perasaan seksual yang mulai muncul bisa menakutkan, membingungkan dan menjadi sumber perasaan salah dan frustrasi. (4) Remaja sering menjadi terlalu percaya diri dan ini bersama-sama dengan emosinya yang biasanya meningkat, mengakibatkan sulit menerima nasihat dan arahan oang tua.

Menurut Heaven (2010), yang menyatakan bahwa iklim keluarga dan perilaku orang tua berpengaruh terhadap nilai-nilai keagaaman anaknya. Pendidikan informal memiliki peran dan kontribusi yang besar dalam keberhasilan pendidikan seorang peserta didik. Namun, pendidikan informal terutama dalam keluarga belum efektif, belum memberikan kontribusi yang berarti dalam mendukung pencapaian kompetensi dan pembentukkan karakter pada peserta didik. Penyebabnya menurut Zubaedi (dalam Kurniawan, 2013, hlm. 105), kemungkinan karena kesibukan dan aktivitas kerja yangg dilakukan orang tua relatif tinggi dan kurangnya pemahaman orangtua dalam mendidik anak di lingkungan keluarga.

Unsur pembentuk moral lainnya adalah sekolah. Sekolah merupakan salah satu tempat peserta didik mendapatkan pendidikan secara formal, bukan hanya tempat kegiatan belajar mengajar berlangsung dan mencari ilmu melainkan juga tempat berkumpul, bermain dan berbagi keceriaan antarsiswa. Oleh karena itu peran guru berpengaruh cukup besar untuk membentuk karakter siswa yang bermoral bukan hanya untuk menjadikan siswanya pintar dan cerdas. Salah satu dari tujuan penyelenggaraanya pendidikan ialah membentuk sikap moral serta watak siswa yang berbudi luhur. Berdasarkan hal itu, pendekatan pendidikan dan mata pelajaran yang membantu untuk membentuk kepribadian peserta didik menjadi pribadi yang lebih baik dan bermoral sangat diperlukan. Dasar pertimbangan utama dan bersifat umum adalah belajar dan mengajar berlangsung secara interaktif yang melibatkan berbagai komponen yang saling konsisten satu dengan yang lainnya untuk mencapai tujuan pengajaran yang telah ditetapkan. Pendidikan ini merupakan usaha untuk menyiapkan siswa supaya dapat berperan aktif dan positif dalam hidupnya baik sekarang maupun dimasa yang akan datang.

\section{METODE PENELITIAN}

Dalam penelitian ini penulis menggunakan metode kualitatif, dengan menjelaskan lebih menekankan pada kekuatan analisis data pada sumber-sumber data yang ada. Oleh karena itu, peneliti ini merupakan telaah atau kajian pustaka yang merupakan data verbal, hal ini penulis melakukan dengan cara menuliskan, mengedit, memaparkan, mengklafisikasi, dan mengkajinya. Hal ini sesuai dengan penggunaan Moleong (2004) terhadap istilah deskriptif sebagai karakteristik dari pendekatan kualitatif karena uraian datanya bersifat deskriptif. Subjek penelitian ditentukan dengan teknik purposive sampling. Subjek Penelitian ini terdiri dari kepala sekolah, para guru, dan orang tua di 
SMP Negeri 1 Sragi. Pengumpulan data dalam penelitian ini dilakukan dengan wawancara mendalam dan dokumentasi. Teknik analisis data dalam penelitian ini dengan melakukan reduksi data, kategorisasi, display/penyajian, dan pengambilan kesimpulan.

\section{HASIL DAN PEMBAHASAN}

\section{A. Peran Orang Tua dalam Mengembangkan Religiusitas Remaja}

Berdasarkan hasil observasi dan wawancara di SMP Negeri 1 Sragi diketahui bahwa orang tua mempunyai peran penting dalam membina sikap keagamaan remaja agar remaja tidak terjerumus dalam jalan yang sesat. Dengan pembinaan yang tepat remaja akan memiliki akidah, tauhid, akhlak, dan nilai manfaat yang banyak di dalam kehidupan. Orang tua menginginkan anaknya tumbuh dan berkembang dengan agama yang baik, tapi setiap orang tua tentu memiliki cara yang berbeda-beda dalam menerapkan pembinaannya. Sesuai dengan kemampuan, keadaan, dan kebutuhan masing-masing.

Adapun peran orang tua dalam membina sikap keagamaan remaja dirinci sebagai berikut.

\section{Sebagai Pendidik}

Orang tua atau wali murid di SMP Negeri 1 Sragi telah melakukan perannya dengan cukup baik. Hal ini berdasarkan hasil penelitian yang menunjukkan bahwa orang tua memberikan pembinaan agama terhadap remaja dalam kehidupan sehari-hari. Pembinaan tersebut, yakni (a) menanamkan nilai-nilai ajaran agama seperti ajaran tauhid, keimanan. Misal dengan menyampaikan rukun iman, rukun Islam, dan menanamkan akhlak yang baik pada remaja; (b) memperhatikan ibadah remaja terutama ibadah salat lima waktu, puasa sunnah, dan lainnya; (c) menganjurkan remaja untuk aktif mengikuti kegiatan keagamaan yang ada di lingkungan setempat, seperti belajar di TPA, kajian ilmu agama remaja Islam Masjid, yasinan, pengajian rutinan dan lainnya agar pengetahuan agama remaja dapat bertambah; (d) memberikan teladan kepada remaja.

Selain mengajarkan nilai-nilai agama secara teori orang tua juga memberikan contoh pelaksanaannya agar remaja mengikutinya. Misal orang tua menganjurkan salat berjamaah, maka mereka memberikan contoh dengan aktif berjamaah. Dengan cara itu remaja dapat mengembangkan perilaku religiuistasnya. Religiusitas yang ditanamkan orang tua sangat berperan dalam pembentukan perilaku anak. Pembentukan tersebut akan membawa anak dalam pertumbuhan dan perkembangan yang baik. Anak memerlukan pendidikan dan persyaratan, pengawasan dan pemeliharaan yang terus menerus sebagai pelatihan dasar dalam pembentukan kebiasaan dan sikap agar memiliki kemungkinan untuk berkembang secara wajar dikehidupan (Jalaludin, 2015, hlm 23).

\section{Melakukan Pengawasan}

Dalam membina sikap keagamaan remaja orang tua juga berperan sebagai pengawas. Artinya orang tua memiliki tanggung jawab untuk melakukan pengawasan 
terhadap tindakan dan segala hal yang dilakukan oleh remaja. Pengawasan yang dilakukan orang tua bukan bermaksud untuk merenggut hak-hak si remaja, melainkan sekadar memberikan kebebasan yang tetap ada batasan sesuai dengan moral agama. Pada dasarnya remaja sangat rentan dipengaruhi oleh lingkungan sekitar, seperti lingkungan pergaulannya. Berdasarkan hasil penelitian, penulis menemukan tindakan yang dilakukan oleh orang tua dalam melakukan pengawasan yang diantaranya melakukan pengawasan terhadap lingkungan pergaulan remaja. Dalam hal ini mereka melarang remaja bergaul dengan teman yang buruk dan remaja wanita dilarang keluar pada malam hari kecuali ada keperluan lain yang penting.

\section{B. Peran Orang Tua dalam Mengembangkan Perilaku Moral Remaja}

Muryono (2009, hlm 17) menyatakan bahwa perilaku moral adalah tingkah laku yang sesuai dengan moral. Pandangan perilaku moral seorang yang benar diharapkan akan menjadikan remaja bertingkah laku yang bermoral. Namun, dapat terjadi seorang yang memiliki pandangan moral yang tinggi, bertingkah laku yang melanggar moral. Oleh karena itu, mengembangkan pandangan moral saja belum menjamin orang tersebut memiliki tingkah laku yang bermoral. Misalnya seorang remaja memahami betul bahwa mencuri itu tidak baik karena menyebabkan kerugian dan kesedihan kepada orang lain. Namun, anak tersebut tetap melakukan pencurian, maka dapat dikatakan tingkah laku moral anak tersebut belum diterapkan.

Adapun peranan orang tua dalam perkembangan tingkah laku bermoral pada remaja, antara lain (a) memberikan contoh yang sangat penting dalam perkembangan moral anak. Anak meniru tingkah laku orang tua. Oleh karena itu, orang tua semestinya memiliki kepribadian yang baik dan mantap dalam nuansa moralitasnya. (b) menerapkan disiplin. Kedisiplinan yang diberikan oleh orang tua terhadap anak merupakan salah satu faktor yang menunjang penerapan tingkah anak dalam menerapkan tingkah laku moral.

Teknik disiplin yang digunakan oleh orang tua, yakni dengan cara membangkitkan perasaan sayang (afeksi) terhadap orang yang menegakkan disiplin. Anak tidak mau melakukan suatu tindakan yang salah karena ia menyayangi orang tua dan gurunya. Adapun beberapa metode yang dapat diberikan kepada anak untuk mempelajari perilaku moral sebagai berikut. (a) Belajar dengan coba-ralat. Mereka melakukan sesuatu dengan mencoba pola perilaku tertentu untuk melihat apakah itu memenuhi standar sosial dan memperoleh persetujuan sosial. Bila tidak, mereka mencoba metode lain dan seterusnya hingga suatu saat secara kebetulan dan bukan karena direncanakan. (b) Pendidikan langsung. Dalam belajar berperilaku sesuai dengan tuntunan masyarakat. Anak pertama-tama harus belajar memberi reaksi tertentu yang tepat dalam situasi tertentu. Ini mereka lakukan dengan mematuhi peraturan yang diberikan orang tua dan orang lain yang berwenang. (c) Identifikasi. Bila remaja 
mengidentifikasi dengan orang yang dikaguminya, mereka meniru pola perilaku dari orang tersebut secara tidak sadar dan tanpa tekanan dari mereka.

Belajar berperilaku dengan cara yang disetujui masyarakat merupakan proses yang panjang dan terus berlanjut hingga masa dewasa. Ini merupakan proses yang penting di masa remaja. Sebelum remaja masuk ke kehidupan dewasa, mereka diharapkan mampu membedakan yang benar dan salah dalam situasi sederhana dan meletakkan dasar bagi perkembangan hati nurani. Sebelum masa remaja berakhir, remaja diharapkan mengembangkan skala nilai dan hati nurani untuk membimbing mereka bila harus mengambil keputusan moral. Dengan demikian, maka penting sekali peranan orang tua dalam perilaku moral remaja, karena orang tua merupakan pendidik pertama yang diterima anak ketika mereka terlahir ke dunia.

\section{Peran Guru dalam Mengembangkan Perilaku Moral Remaja}

Wawasari (2005, hlm. 23) mengatakan beberapa pendapat dan berbagai macam tokoh dengan sudut pandang masing-masing. Adams \& Dicley (dalam Wawasari, 2005) menyatakan bahwa peran guru sebagai berikut. (1) Guru sebagai tenaga pengajar. (2) Guru sebagai pembimbing. (3) Guru sebagai ilmuwan (4) Guru sebagai pribadi. Sedangkan tugas guru yang utama adalah menyempurnakan, membersihkan, dan menyucikan, serta membawa hati manusia untuk mendekatkan dirinya pada Allah SWT. (Ghazali dalam Ngainum, 2009).

Peran guru memiliki pengaruh besar dalam meningkatkan moral siswa. Guru sebagai pendidik harus bisa mendidik siswanya kearah yang lebih baik, mampu membentuk dan membangun sikap siswa agar lebih menghargai maupun menghormati orang lain, memiliki rasa toleransi yang tinggi. Peningkatan moral tersebut dilakukan dengan metode keteladanan dan pembiasaan-pembiasaan serta halhal yang baik.

Dari hasil wawancara peran guru sebagai pendidik tidak hanya mengajarkan materi saja, tetapi dengan memberi keteladanan yang baik terhadap siswanya. Selain itu, melakukan pembiasaan-pembiasaan seperti membiasakan salam ketika memulai ataupun mengakhiri sapaan dan membiasakan berdoa ketika memulai dan mengakhiri pembelajaran dan juga mengarahkan siswa supaya berperilaku baik. Guru sebagai pendidik juga harus bisa menjadi panutan bagi muridnya. Hal ini sesuai dengan prinsipprinsip psikologi dan etika yang dapat membantu sekolah untuk meningkatkan seluruh tugas pendidikan dalam membangun kepribadian siswa yang kuat. Terkait itu, Adams dan Dicley (dalam Wawasari 2005, hlm. 23) menjelaskan bahwa peran guru ialah sebagai pengajar, pembimbing, ilmuan, dan sebagai pribadi. Guru sebagai pribadi yang mana guru mampu memberikan panutan yang baik bagi siswa dan memberikan contoh sikap teladan dengan memberikan keteladanan melalui cara bersikap guru dalam 
bergaul dan kedisiplinan serta memberikan pembiasaan agar siswa dapat berperilaku santun

\section{Peran Guru dalam Mengembangkan Religiusitas Remaja}

Dari hasil wawancara terhadap beberapa guru mata pelajaran di SMP Negeri 1 Sragi terdapat beberapa peran dalam mengembangkan sikap religiusitas remaja, yaitu sebagai pengajar, pendidik, teladan, motivator, pembimbing, pemimpin, pendorong dasar keimanan, pendorong akal siswa, sumber belajar. Selain itu, metode yang di gunakan guru dalam mengembangkan religiusitas siswa, yaitu metode ceramah dalam menyampaikan pelajaran atau pendidikan karakter religius siswa para guru. Salah satunya menggunakan metode ceramah menyisipkan ajaran agama setiap mengajarkan mata pelajaran, metode keteladanan. Keteladanan adalah cara yang paling efektif untuk mendidik karakter religius siswa.

Sosok seorang guru adalah teladan bagi siswa, baik dari tingkah lakunya maupun sopan santunnya. Pendidikan keteladanan menjadi salah satu upaya untuk memperbaiki serta membimbing siswa agar memiliki akhlak yang mulia. pendidikan dengan nasihat. Nasihat adalah cara yang digunakan oleh seorang guru untuk memberikan petunjuk kepada siswa, peringatan serta teguran kepada siswa adalah cara yang efektif dalam mendidik karakter religius siswa. Nasihat yang tulus dari seorang guru akan memberikan pengaruh positif terhadap siswa sehingga mereka akan menerima dengan terbuka suatu hukuman atau penghargaan.

Hukuman adalah salah satu cara yang digunakan beberapa guru untuk mengarahkan tingkah laku siswa agar sesuai dengan tingkah laku yang diharapkan dan menghentikan tingkah laku yang menyimpang. Hukuman adalah cara supaya siswa tersebut jera dengan perbuatannya. metode pembiasaan, Pembiasaan adalah proses pembentukan sikap dan perilaku yang sifatnya terus-menerus dan dilakukan kontinyu. Pembiasaan perilaku religius diterapkan di dalam kelas agar siswa mampu membiasakan diri dengan kegiatan tersebut. Kegiatan pembiasaan seperti berdoa sebelum pelajaran dimulai, salam sebelum pembelajaran.

\section{SIMPULAN}

Dari hasil penelitian dapat disimpulkan bahwa guru dan orang tua memiliki peranan penting dalam mengembangkan perilaku moral remaja. Selain itu, cara yang mereka gunakan pun cukup beragam dalam membentuk sikap religiusitas dan perilaku moral di kalangan remaja. Misalnya, memperhatikan ibadah anak remaja, mengikutsertakan remaja dalam kegiatan agama, menerapkan disiplin, dan menjadi contoh yang baik untuk remaja sebagai cara meningkatkan perilaku moral yang baik bagi remaja. Sedangkan bagi guru, peran yang mereka lakukan untuk mengembangkan perilaku dan moral remaja, yaitu dengan menjadi contoh yang baik bagi siswa-siswinya dan menerapkan kedisiplinan. Dalam mengembangakan religiusitas remaja, guru beperan cukup signifikan seperti 
menyisipkan ceramah kedalam mata pelajaran, mengawali, dan mengakhiri pelajaran dengan berdoa.

\section{DAFTAR PUSTAKA}

Gunarsa, S. D. dan Singgih D. G. (2013). Psikologi Untuk Membimbing. Jakarta: BPK. Gunung Mulia.

Heaven, P. C. L., Joseph C., dan Peter L. (2010). Parental Styles and Religious Values Among Teenagers: A 3-Year Prospective Analysis. The Journal of Genetic Psychology, hlm. 98.

Hurlock, E. B. (1999). Psikologi Perkembangan, Suatu Pendekatan Sepanjang Rentang Kehidupan. Jakarta: Erlangga.

Jalaludin R. (2015). Psikologi Agama. Jakarta: Raja Grafindo Persada.

Kurniawan, S. (2017). Pendidikan Karakter: Konsepsi \& Implementasinya secara Terpadu di Lingkungan Keluarga, Sekolah, Perguruan Tinggi, dan Masyarakat. Yogyakarta: Ar-Ruz Media.

Muhyani. (2012). Pengaruh Pengasuhan Orang Tua dan Peran Guru di Sekolah Menurut Persepsi Murid terhadap Kesadaran Religius dan Kesehatanmental. Jakarta: Kementerian Agama Republik Indonesia Direktorat Jenderal Pendidikan Islam Direktorat Pendidikan Tinggi Islam.

Moleong, L. (2004). Metodelogi Penelitian Kualitatif. Bandung: Remaja Rosdakarya.

Muryono, S. (2009). Empati, Penalaran Moral, dan Pola Asuh: Telaah Bimbingan Konseling. Yogyakarta: Gala Ilmu Semesta.

Ngainum, N. (2009). Guru Inspiratif. Yogyakarta: Pustaka Pelajar.

Wirawan, S. (2002). Psikologi Remaja. Jakarta: Raja Grafindo Persada.

Sidik, J. (2010). Genk Remaja, Anak Haram Sejarah ataukah Korban Globalisasi. Yogyakarta: Kanisius.

Wawasari. (2005). Tugas Guru Tenaga Kependidikan. Jakarta: Departemen Agama. 
186 | Firmansyah - Peran Orang Tua ... 